[Transaction ]

\title{
Influence of Men's Clothing and Hairstyle on the Evaluation of Professionalism and Preference
}

\author{
Seung-Hee Kang • Myoung-Hee Lee \\ Dept. of Clothing \& Textiles, Sungshin Women's University \\ Received May 12, 2009; Revised May 31, 2009; Accepted June 8, 2009
}

\section{남성 의복과 헤어스타일이 전문성 및 선호도 평가에 미치는 영향}

\author{
강승희 $\cdot$ 이명희 ${ }^{\dagger}$ \\ 성신여자대학교 의류학과 \\ 접수일(2009년 5월 12일), 수정일(2009년 5월 31일), 게재확정일(2009년 6월 8일)
}

\begin{abstract}
The purpose of this study was to investigate the effect of perceiver's gender, clothing, and hairstyle on the visual evaluation of men's professionalism and preference. A quasi-experimental method by questionnaire was used. The experimental design was a $2 \times 8 \times 2$ (perceiver's gender $\times$ clothing $\times$ hairstyle) factorial design by 3 independent variables. The stimuli were 16 photographs of a man in his twenties. The upper clothing of the man included tailored collar jackets in beige and dark blue colors, and jumpers and sweaters in beige, dark blue, and red colors. The lower clothing of the men included jean pants. Two types of the hairstyles included short hair and medium length hair. The subjects were 208 men and 223 women in Seoul, Korea. Wearing a beige sweater with jean pants was evaluated high in intellectual image, a red jumper was perceived low in intellectual image, and a beige tailored collar jacket was evaluated low in potent image. Men's short hairstyle was evaluated to be more professional than the medium length hair. Male perceivers liked short hair more than medium length hair, but female perceivers evaluated both hairstyles similarly. In the case of women, the preferences of tailored collared jacket and soutien collared jumper were similar, but jumper was preferred to jacket in the case of men. Male perceivers showed more positive feedback towards jean pants with soutien collared jumper than jeans with tailored collared jacket, which indicated that men showed more conservative attitude towards the outfit than women. The man who was wearing a jumper with short hair was evaluated positively and the man who was wearing a jacket with medium length hair was evaluated negatively when the attires were coordinated with jean pants. In conclusion, medium length hairstyle with a beige jacket and short hairstyle with a red sweater were evaluated as professional image; and the results indicated that clothing and hairstyle interact with each other and influence the evaluation of professionalism.
\end{abstract}

Key words: Professionalism, Preference, Jacket, Jumper, Hairstyle; 전문성, 선호도, 재킷, 점퍼, 헤어 스타일

Corresponding author

E-mail: mhlee@ sungshin.ac.kr

This work was supported by the Sungshin Women's University Research Grant of 2009.

\section{Introduction}

Recently, unisexualization of clothing is so widely spread that the sexual boundary between men and 
women has been blurred. Additionally as the five day workweek system has been adopted, more people have come to enjoy weekends and their leisure time more actively than ever, which now leads to the popularity of casual wear looks among people in everyday clothes. Such trends made a great impact on the men's appearance so that it is allowed to wear even jean pants and tailored collared jacket or casual jacket at the work place. Hairstyle is considered an advantageous way to create different looks and make an influence on image creation among young men, therefore, the young men are trying out diverse versions of hairstyles.

Inter personal relationships can be affected by one's own appropriate image expressed through the change of looks and hairstyle. An individual can express an appropriate image for interpersonal relationships by changing his/her appearance and hairstyle. As women's appearance cue such as garment and body type conveyed different level of professional image to perceivers (Thurston et al., 1990), appearance of men also may influence judgment of professional image and favorable impression. The results of the study conducted on male subjects showed that career type could be inferred by clothing, and clothing and hairstyles provided clues for evaluation of an individual's competence (Kim \& Ryu, 2004; Lee \& Koh, 1995a, 1995b).

Additionally, the perceiver's gender is known to significantly affect the manner in which the other party's appearance is perceived. For example, in previous studies, it was found that differences existed by gender in the evaluation dimensions and sociability; therefore, female perceivers showed more positive feedback towards the outfit style of men (Lee \& Kim, 1998), and female perceivers had tendency to more highly evaluate the potency of a man's hairstyle than male perceivers did (Kim \& Ryu, 2004),

The previous studies show that clothing and hairstyle are the meaningful cues that affects person's impression or image perception. However, not many systematic studies have been conducted on men's image perception related to clothing and hairstyle trends in comparison to the studies of women's image. Furthermore, the studies conducted on the men's profes- sional image are very scarcely found. Also, as young men now are more frequently wearing jeans as part of everyday dress, jeans accompanied by a casual jacket are more likely to be selected than a formal suit even for formal occasions. For this reason, it is important to investigate what types of upper wear look more professional and are preferred by other people when coordinated with jean pants. Therefore, this study is intended to discuss regarding the difference in the evaluation of men's professional image and preference by the styles of men's casual wear and hairstyle and by the perceiver's gender.

The objectives of this study were to investigate the effect of perceiver's gender, clothing, and hairstyle on the visual evaluation of men's professionalism and preference, and to disclose what characteristics of professional image affect preference evaluation.

\section{Literature Review}

\section{Men's Clothing and Impression Formation}

Impression formation is a process of consistently understanding and perceiving others by integrating the diverse information that we obtain (Jeong, 1982). To form an impression of another person, we tend to use clues such as body shape, face, hairstyle, clothing and accessories. However, not all clues are delivered with the same emotional intensity; when forming impressions, people tend to selectively perceive only the noticeable clues. Noticeable clues are consistently remembered and create a memory trace that remains for a long time, having a great impact on the formation of an impression. Despite the fact that people tend to form impressions of others based on very limited, fragmentary information, they are prone to believing that they can understand almost everything about the inner characteristics of the other person. Such an impression, once formed, is often strongly and consistently maintained. Another tendency is also exhibited when new information is added that contradicts or is in discord with the original impression, it is ignored or analyzed in a distorted manner (Kim, 2002).

Clothing styles and colors are studied in variety as clothing variables in the research regarding impres- 
sion formation. Behling (1995) carried out a study on the style of student dress worn to high school; the five clothing styles included formal wear, preppy, up to date, dividends, and poor people style. According to his study results, student in formal wear were perceived to have higher academic potential and intelligence than those in other styles. According to the study by Rees et al. (1974), in case of college students, the look of wearing a neck-tie was evaluated as more intelligent at an interview, while the look of not wearing a neck-tie was evaluated as more intelligent on campus. From the results of the study by Lee and Koh (1995a, 1995b), personal characteristics and clothing style traits played a role as a clue when evaluating appearance and ability, which also made it possible to infer the type of career. The navy blue formal suit with single button which was among the corporate worker clothes category obtained highest scores in terms of attractiveness and ability. It was also found that the clothing type could make a greater impact on appearance and ability than the face attractiveness. Lee and Kim (1998) studied on the impression formation of male teachers. Among the color of clothing, the navy blue colored cloth obtained the positive feedback with the polite and trustworthy impression. Also semi-formal outfit obtained the more positive feedback than formal outfit or causal wear. Lee (1993) studied on the image of male students wearing a regular shirts with a jacket or a jumper. All of male and female perceivers evaluated that the jacket created more intelligent look than the jumper did. The appearance of male students wearing a round neckline shirts with a jumper or a jacket was evaluated to create very active impression.

\section{Men's Hairstyle and Impression Formation}

As hairstyles can influence the impression formation, it is also important to study such topic in the area of men's hairstyle. Pancer and Meindl (1978) studied the impressions of the length of men's hair, and found out that men with long hair were sensed as more liberal and open-minded than the men with short hair. From the research on the preference of male hairstyle, Peterson and Curran (1976) found out that majority of the female college students generally preferred short-haired males. This study also showed that females who preferred short-haired males were more conservative, and those who preferred long-haired males were more liberal on the ground of the similarity-attraction theory. Han and Ha (2003) conducted a study on the sex-role perception of hairstyle, and the results showed that men who had short hairstyles or black hair colors were evaluated more masculine.

From the results of Kim and Ryu's study (2004), it was evaluated that slightly short hair presented more potent image than long hair, and short hair was considered more sophisticated and better-looking than long hair. Ha and Lee (2008) studied the image of male hairstyle by looking at color and texture. The results showed that the black straight hair presented the highest dignity, while black wavy hair was evaluated as highly active. Lee and Yang (2007) researched preference of male hair trend by different regions and found out that a typical short hairstyle was preferred in all regions compared to more trendy hairstyle. The reason for the results was because a typical short hairstyle was appropriate for the regional environment and created a neat and tidy image.

\section{Methods}

\section{Instrument}

A quasi-experimental method by questionnaire was used. The experimental design was a $2 \times 8 \times 2$ (perceiver's gender $\times$ clothing $\times$ hairstyle) factorial design by 3 independent variables.

The stimuli were sixteen photographs $(10 \times 18 \mathrm{~cm})$ of a male model which were color output by computer simulation. To produce a stimulus, a man in his 20 's with an oval-shaped face was recruited as a model. The model's height and weight were $178 \mathrm{~cm}$ and $70 \mathrm{~kg}$, respectively. The model's posture was attentive, and his facial expression was consistently maintained. The model with short hair wore 3 different types of upper clothing in beige color, and pictures were taken each time. After taking photographs of the model, his hair length and clothing color were changed into the different ones using a CAD system. 


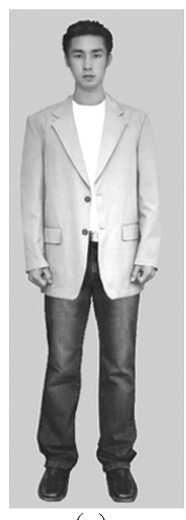

(a)

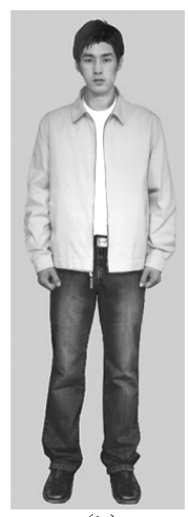

(b)

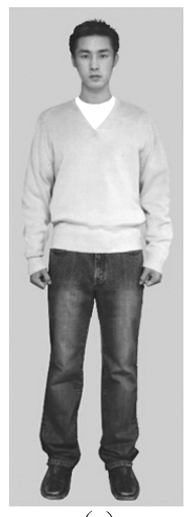

(c)
Fig. 1. The stimulus photograph.

The upper clothing of the stimuli were a tailored collared jacket, a soutien collared jumper, and a Vneck line sweater. The colors of the clothes were jackets in beige and dark blue; jumpers in beige, dark blue, and red; and sweaters in beige, dark blue, and red. The inner wear of the upper clothing was controlled with a white T-shirts, and the lower clothing was controlled with jean pants. Only upper clothing of the stimuli was changed into 8 variations; these were beige jackets, dark blue jackets, beige jumpers, dark blue jumpers, red jumpers, beige sweaters, dark blue sweaters, and red sweaters. The hairstyles were short hair and medium length hair. The background color of the stimuli was light gray. <Fig. 1> presents the stimuli photographs; $a$ is the model with short hair wearing a jacket, $\mathrm{b}$ is the model with medium length hair wearing a jumper, and $\mathrm{c}$ is the model with short hair wearing a sweater.

To evaluate the stimuli, 7-point bipolar adjectives of semantic differential scale were used, and the items were collected in the previous research (Joo \& Lee, 1999; Lee \& Kim, 1998; Thurston at al., 1990). It was composed of five professionalism items and one preference item. Cronbach's $\alpha$ reliability coefficient of the 5 items was .757 , and the sum of the items was named professionalism. Demographic variable included the gender of perceivers.

\section{Data Collection and Analysis}

The subjects were 208 men and 223 women in
Seoul, Korea. Sixteen percent of the subjects were in the age range from 18 to $19,52.2 \%$ in the age range from 20 to $29,26.3 \%$ from 30 to 39 , and $5.5 \%$ from 40 to 59. One subject was asked to respond to two different stimuli with clothing and hairstyle differently combined. Quota sampling was conducted in order to distribute subjects whose age were over thirty into each group as one-third of total group number.

The data were analyzed by using Cronbach's a reliability coefficient, three-way ANOVA, and Duncan's multiple range test, and multiple regression analysis.

\section{Results and Discussion}

\section{The Difference of Professionalism according to Perceiver's Gender, Clothing, and Hair- style}

Three-way ANOVA was undertaken to investigate whether perceiver's gender, clothing, and hairstyle were influenced on the evaluation of professionalism.

Among the evaluation of professionalism items, clothing had significant influence on potent image and intellectual image. The beige jacket was evaluated the lowest in potent image. The red sweater was evaluated relatively low in potent image. The jumpers in all three colors were evaluated high in potent image. The beige sweater was evaluated the highest in intellectual image, but the red jumper was evaluated the lowest in intellectual image.

Therefore, the results showed that wearing a beige sweater with jean pants was evaluated high in intellectual image, wearing a red jumper was perceived low in intellectual image, and wearing a beige tailored collar jacket with jean pants was perceived low in potent image.

The results revealed that men's hairstyle gave significant influence on the evaluating of professionalism (Table 1). The short hairstyle was evaluated to be more professional than the medium length. Such support the research conducted by Kim and Ryu (2004) which had results that there was higher potency in men's short hair than long hair.

There were no interaction effects in evaluating of professionalism by three independent variables. There 
Table 1. Difference of professionalism according to perceiver's gender, clothing, and hairstyle

\begin{tabular}{|c|c|c|c|c|c|c|c|c|}
\hline \multirow{2}{*}{\multicolumn{2}{|c|}{ source of variance }} & \multirow[b]{2}{*}{ df } & \multirow{2}{*}{$\begin{array}{c}\text { professional- } \\
\text { ism } \\
F\end{array}$} & \multicolumn{5}{|c|}{ the items of professionalism } \\
\hline & & & & $\begin{array}{c}\text { professional } \\
F\end{array}$ & $\begin{array}{c}\text { potent } \\
\quad F\end{array}$ & $\begin{array}{c}\text { mature } \\
F\end{array}$ & $\begin{array}{c}\text { intellectual } \\
F\end{array}$ & $\begin{array}{c}\text { confident } \\
F\end{array}$ \\
\hline \multicolumn{2}{|c|}{$\begin{array}{l}\text { gender (A) } \\
\text { clothing (B) }\end{array}$} & 1 & .07 & 1.36 & .14 & .77 & .34 & 1.76 \\
\hline clo & $g(B)$ & 7 & .88 & .7 & $2.17^{*}$ & .86 & $2.52 *$ & 1.46 \\
\hline \multicolumn{2}{|c|}{ hairstyle (C) } & 1 & $33.86^{* *}$ & $9.14 * *$ & $15.35^{* *}$ & $25.05 * *$ & $13.17 * *$ & $26.36 * *$ \\
\hline \multicolumn{2}{|c|}{$\mathrm{A} \times \mathrm{B}$} & 7 & $2.18^{*}$ & 1.98 & 1.11 & 1.29 & $2.42 *$ & 1.01 \\
\hline \multicolumn{2}{|c|}{$\mathrm{A} \times \mathrm{C}$} & 1 & 1.62 & 1.35 & .12 & .05 & $6.37 *$ & .03 \\
\hline \multicolumn{2}{|c|}{$\mathrm{B} \times \mathrm{C}$} & 7 & $2.13^{*}$ & 1.98 & 1.07 & 1.54 & $2.27 *$ & 1.12 \\
\hline \multicolumn{2}{|c|}{$\mathrm{A} \times \mathrm{B} \times \mathrm{C}$} & 7 & 1.02 & 1.17 & 1.14 & 2.00 & .41 & 1.44 \\
\hline \multicolumn{2}{|c|}{ residual } & 818 & & & & & & \\
\hline variables & category & $N$ & $M$ & $M$ & $M$ & $M$ & $M$ & $M$ \\
\hline \multirow{2}{*}{ gender } & male & 409 & 3.91 & 3.60 & 4.01 & 3.64 & 3.87 & 4.45 \\
\hline & female & 441 & 3.90 & 3.49 & 4.04 & 3.71 & 3.93 & 4.33 \\
\hline \multirow{8}{*}{ clothing } & beige JK & 111 & 3.75 & 3.32 & $3.72 \mathrm{~b}$ & 3.50 & $3.83 \mathrm{bc}$ & 4.40 \\
\hline & dark blue JK & 112 & 3.90 & 3.70 & $3.97 \mathrm{ab}$ & 3.54 & $3.86 \mathrm{bc}$ & 4.42 \\
\hline & beige JP & 108 & 3.92 & 3.67 & $4.06 \mathrm{a}$ & 3.81 & $3.75 \mathrm{bc}$ & 4.31 \\
\hline & dark blue JP & 103 & 4.02 & 3.62 & $4.13 \mathrm{a}$ & 3.76 & $4.02 \mathrm{abc}$ & 4.58 \\
\hline & red JP & 107 & 3.93 & 3.51 & $4.11 \mathrm{a}$ & 3.75 & $3.68 \mathrm{c}$ & 4.61 \\
\hline & beige ST & 102 & 4.01 & 3.52 & $4.24 \mathrm{a}$ & 3.68 & $4.25 \mathrm{a}$ & 4.36 \\
\hline & dark blue ST & 103 & 3.90 & 3.46 & $4.12 \mathrm{a}$ & 3.69 & $4.12 \mathrm{ab}$ & 4.13 \\
\hline & red ST & 104 & 3.86 & 3.57 & $3.88 \mathrm{ab}$ & 3.75 & $3.76 \mathrm{bc}$ & 4.32 \\
\hline \multirow{2}{*}{ hairstyle } & short & 425 & 4.09 & 3.69 & 4.19 & 3.88 & 4.06 & 4.63 \\
\hline & medium & 425 & 3.73 & 3.40 & 3.87 & 3.48 & 3.75 & 4.16 \\
\hline
\end{tabular}

$* p<.05, * * p<.01$, a-c: Duncan's multiple range test, JK: jacket, JP: jumper, ST: sweater

were significant interaction effects in evaluating of professionalism by the two variables, between clothing and perceiver's gender or hairstyle. The results are shown in $\langle$ Fig. 2$\rangle-\langle$ Fig. 3$\rangle$.

The evaluation of beige colored jumper was particularly different according to gender $\langle$ Fig. 2 $\rangle$; women perceived the beige colored jumper less professional than men did. The red sweater was evaluated to be more professional by women than by men.

The medium length hairstyle was considered to be more professional than the short hair in the men wearing beige jacket, while short hairstyle was considered to be more professional than medium length hair in the men wearing red sweater (Fig. 3). The results imply that clothing and hairstyle of men give significant influence on the evaluation of professional image by the interaction effect.

A three-way ANOVA was undertaken to investigate whether perceiver's gender, clothing, and hairstyle had interaction effects on the evaluation of items of professional image (Table 1). There were significant interaction effects in evaluating of intellectual image by perceiver's gender with clothing, perceiver's gender with hairstyle, and clothing with hairstyle (Fig. 4) (Fig. 6).

Women perceived the beige tailored collar jacket to be more professional than the beige jumper, while men evaluated the beige jumper to be more professional than the beige jacket (Fig. 4). The evaluation results by female perceivers from this study were consistent with the results of a study by Lee (1993).

The men evaluated short hair more intellectual and medium length hair less intellectual than the women did (Fig. 5). The short hair was evaluated more intellectual than the medium length hair when a model was wearing a beige jacket, while short hair was perceived to be less intellectual than medium length hair when a model was wearing a red jumper (Fig. 6). The medium length hair with a red sweater was evaluated to be low in intellectual image. The results imply that the perception of men's intellectual image was influenced by the interaction between clothing and hairstyle. 


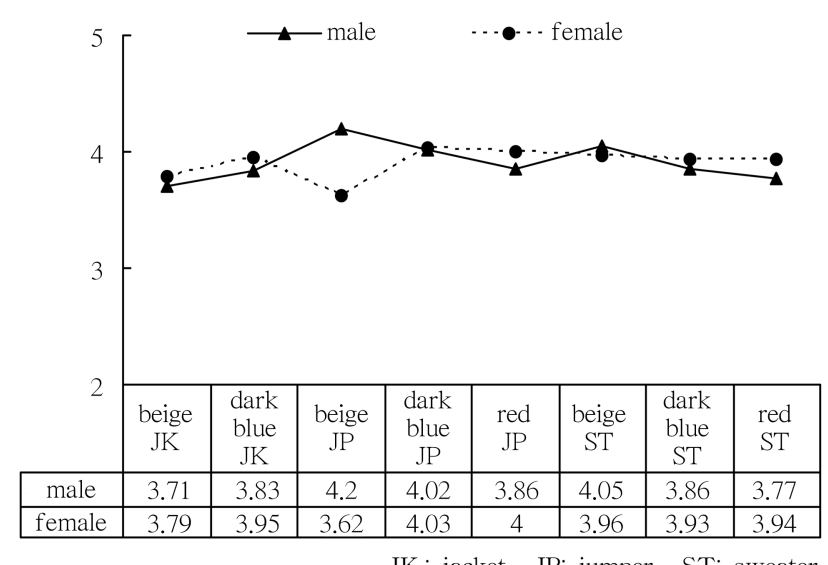

Fig. 2. Interaction effect by perceiver's gender and clothing in professionalism.

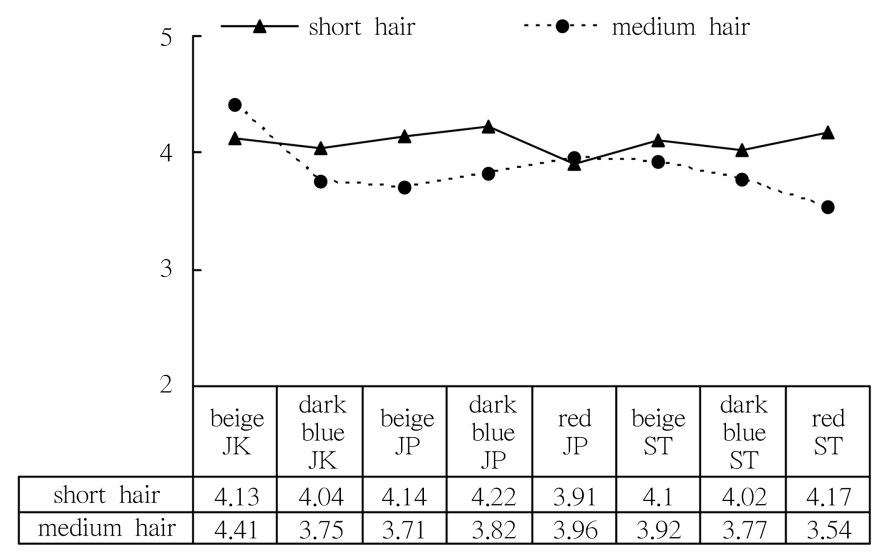

JK.: jacket, JP: jumper, ST: sweater

Fig. 3. Interaction effect by hairstyle and clothing in professionalism.

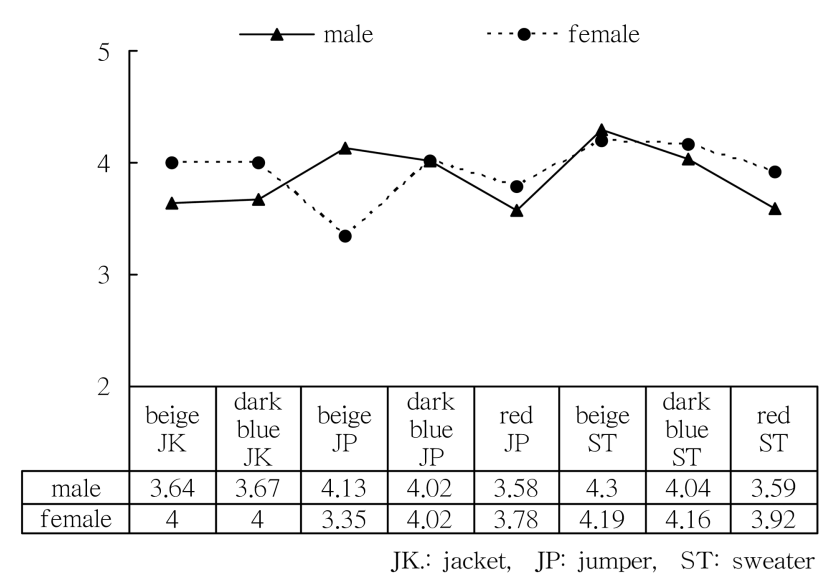

Fig. 4. Interaction effect by perceiver's gender and clothing in intellectual image. 


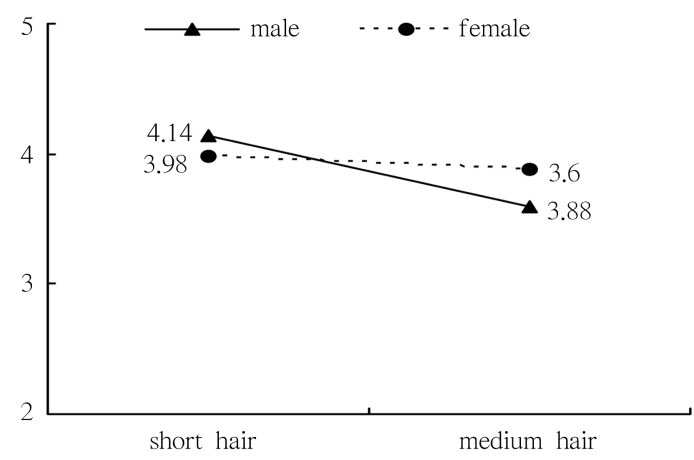

Fig. 5. Interaction effect by perceiver's gender and hairstyle in intellectual image.

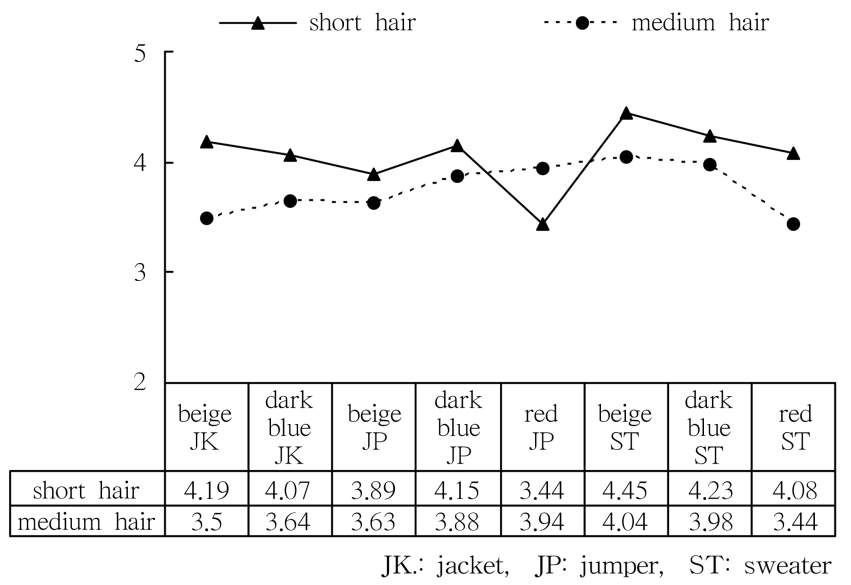

Fig. 6. Interaction effect by hairstyle and clothing in intellectual image.

\section{The Difference of Preference according to Perceiver's Gender, Clothing, and Hairstyle}

A three-way ANOVA was undertaken to investigate whether perceiver's gender, clothing, and hairstyle were influenced on the evaluation of preference (Table 2).

There was no significant difference in evaluating preference according to the perceiver's gender. However, there were significant differences in preference according to the clothing and hairstyle. The short hair was preferred to the medium length hair. This result is consistent with the results of a previous study by Kim and Ryu (2004), which showed that short hair looked better than long hair. Additionally, the beige colored sweater was preferred the most, and the beige jacket was preferred the least.

There were significant interaction effects in evalu- ating of preference by two variables, which were the perceiver's gender with clothing, and the perceiver's gender with hairstyle. The results are shown in $<$ Fig. 7>-<Fig. 8>.

In the case of women, the preference of the jacket and jumper was similar, but the jumper was preferred to the jacket in the case of men. Men liked the beige jumper and the dark blue jumper much more than women did. Men's preference of the beige jacket was especially the lowest. Therefore, male evaluated a model wearing the jean pants with the casual jumper more positive than with tailored collared jacket, but female did not evaluate the two type clothes differently. It can be interpreted that these results are drawn from men's rigid attitude towards the clothing style considering that it looks more appropriate to wear jean pants with casual jumper. 
Table 2. Difference of preference according to perceiver's gender, clothing, and hairstyle

\begin{tabular}{|c|c|c|c|c|c|c|}
\hline source of variance & $\mathrm{df}$ & $\begin{array}{c}\text { preference } \\
F\end{array}$ & $\begin{array}{l}\text { dependent } \\
\text { variables }\end{array}$ & category & $N$ & $M$ \\
\hline \multirow[b]{2}{*}{$\begin{array}{c}\text { gender }(\mathrm{A}) \\
\text { clothing }(\mathrm{B}) \\
\text { hairstyle }(\mathrm{C}) \\
\mathrm{A} \times \mathrm{B} \\
\mathrm{A} \times \mathrm{C} \\
\mathrm{B} \times \mathrm{C} \\
\mathrm{A} \times \mathrm{B} \times \mathrm{C}\end{array}$} & \multirow[b]{2}{*}{$\begin{array}{l}1 \\
7 \\
1 \\
7 \\
1 \\
7 \\
7\end{array}$} & \multirow[b]{2}{*}{$\begin{array}{c}.52 \\
6.84^{* *} \\
13.71^{* *} \\
2.12^{*} \\
7.18^{*} \\
1.77 \\
1.03\end{array}$} & gender & $\begin{array}{l}\text { male } \\
\text { female }\end{array}$ & $\begin{array}{l}409 \\
441\end{array}$ & $\begin{array}{l}3.94 \\
3.85\end{array}$ \\
\hline & & & clothing & $\begin{array}{l}\text { beige JK } \\
\text { dark blue JK } \\
\text { beige JP } \\
\text { dark blue JP } \\
\text { red JP } \\
\text { beige ST } \\
\text { dark blue ST } \\
\text { red ST }\end{array}$ & $\begin{array}{l}111 \\
112 \\
108 \\
103 \\
107 \\
102 \\
103 \\
104\end{array}$ & $\begin{array}{l}3.19 \mathrm{~d} \\
3.45 \mathrm{~cd} \\
4.22 \mathrm{ab} \\
4.18 \mathrm{ab} \\
4.00 \mathrm{ab} \\
4.37 \mathrm{a} \\
3.88 \mathrm{bc} \\
3.96 \mathrm{ab}\end{array}$ \\
\hline residual & 818 & - & hairstyle & $\begin{array}{l}\text { short } \\
\text { medium }\end{array}$ & $\begin{array}{l}425 \\
425\end{array}$ & $\begin{array}{l}4.11 \\
3.69\end{array}$ \\
\hline
\end{tabular}

$* p<.05, * * p<.01$, a-d: Duncan's multiple range test, JK: jacket, JP: jumper, ST: sweater

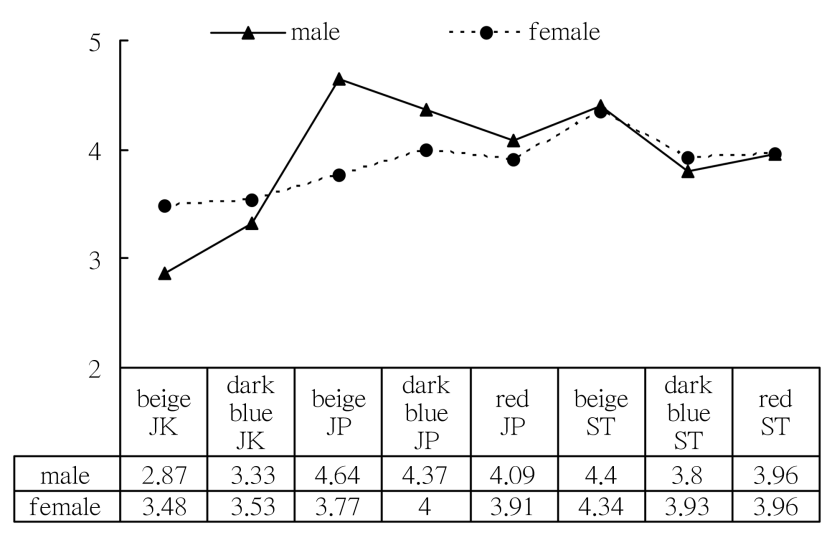

JK: jacket, JP: jumper, ST: sweater

Fig. 7. Interaction effect by perceiver's gender and clothing in preference.

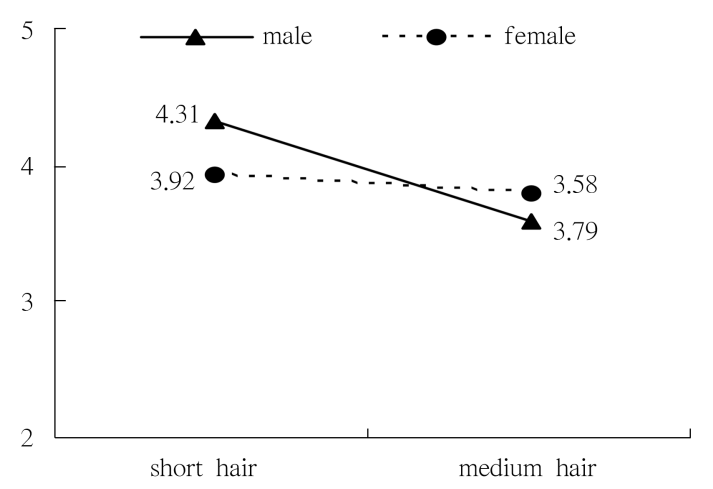

Fig. 8. Interaction effect by perceiver's gender and hairstyle in preference.

In the result of interaction effects by perceiver's gender and hairstyle, men liked short hair more than medium length hair, but women evaluated both hairstyles similarly (Fig. 8). 


\section{The Positions of the Stimuli by the Profes- sionalism and Preference}

The locations of stimuli by 2 axis were investigated to see the evaluation of 16 stimuli by professionalism and preference in two dimension. The result of positioning professionalism on $\mathrm{X}$-axis and preference on Y-axis is presented in 〈Fig. 9>.

Men wearing the beige jumper with short hair were evaluated as the highest in professionalism, and the beige sweater with short hair was evaluated as the next highest. The dark blue jumper with short hair was preferred the most, and the red sweater with short hair was preferred as the second most. Men of beige jacket with medium length hair were evaluated as the lowest in professionalism and preference. These results show that the men who were wearing the jumper with short hair were evaluated positively and tailored collared jacket with medium length hair were negatively when the attires were coordinated with the jean pants.

\section{The Multiple Regression Analysis of Prefer- ence}

The test was executed by the multiple regression analysis which used the stepwise method including the dependent variable of preference and the independent variables of five items of professional image. The result is presented in <Table 3>.

For men perceivers, the preference was influenced most by potent image, next by intellectual, and professional image. The explanatory power of the three image items was $37.7 \%$. For women, potent was the most and the next came intellectual, mature, and confident image. The explanatory power of the four image items was $29.1 \%$.

Both men and women, potent and intellectual image of men's appearance was important to preference. However, compared to men, women considered mature and confident image significant when evaluating preference. So it can be said that women liked mature and confident image more than man did. That is, there were differences on image items affect to preference

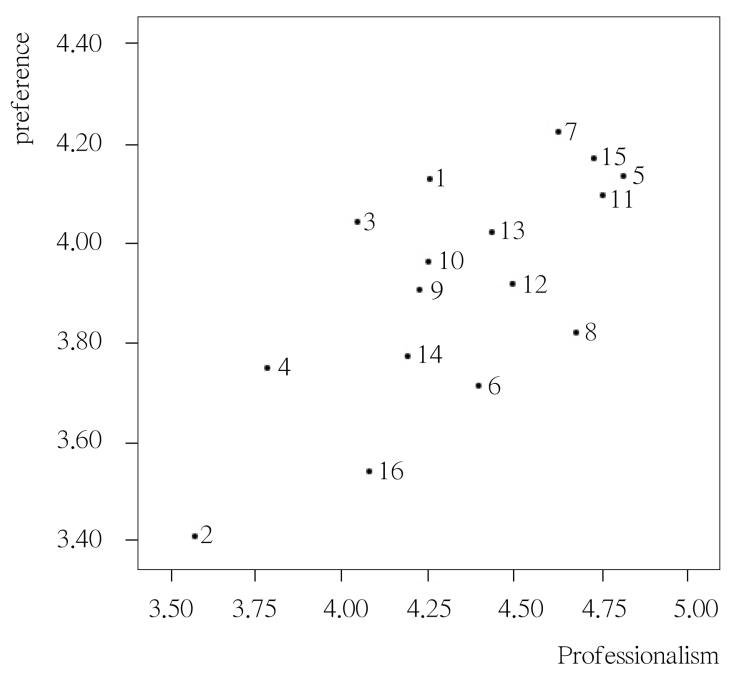
1. beige $\mathrm{JK}-\mathrm{s}$.
5. beige $\mathrm{JP}-\mathrm{s}$.
9. red $\mathrm{JP}^{-\mathrm{s}}$.
13. dark blue ST-s.
2. beige $\mathrm{JK}-\mathrm{m}$. 6. beige $\mathrm{JP}-\mathrm{m}$.
10. red $\mathrm{JP}-\mathrm{m}$.
14. dark blue ST-m.
3. dark blue JK-s. 7. dark blue JP-s.
11. beige ST-s. 15. red ST-s.
4. dark blue JK-m. 8. dark blue JP-m.
12. beige $\mathrm{ST}-\mathrm{m}$.
16. red ST-m.

JK: jacket, JP: jumper, ST: sweater, s.: short hair, m.: medium hair

Fig. 9. The position of professionalism and preference of stimulus. 
Table 3. Multiple regression analysis of preference

\begin{tabular}{|c|c|c|c|c|c|c|c|c|}
\hline \multirow{2}{*}{ item } & \multicolumn{4}{|c|}{ male } & \multicolumn{4}{|c|}{ female } \\
\hline & beta & $t$ & $R^{2}$ & $F$ & beta & $t$ & $R^{2}$ & $F$ \\
\hline potent - impotent & .37 & $7.73 * *$ & \multirow{5}{*}{.377} & \multirow{5}{*}{$81.75^{* *} *$} & .33 & $6.80 * *$ & \multirow{5}{*}{.291} & \multirow{5}{*}{$44.84 * *$} \\
\hline intellectual - not intellectual & .26 & $5.66^{* *}$ & & & .14 & $2.91 * *$ & & \\
\hline professional - unprofessional & .12 & $6.60 * *$ & & & - & - & & \\
\hline mature - immature & - & - & & & .14 & $2.93 * *$ & & \\
\hline confident - not confident & - & - & & & .10 & $2.10 * *$ & & \\
\hline
\end{tabular}

evaluation between men and women.

To both men and women, potent and intellectual image of men's appearance was important when they evaluated preference. However, compared to men, women considered mature and confident image more important when evaluating preference. Therefore, it can be said that women liked mature and confident image more than men did. The results imply that image items influence differently on the preference evaluation between men and women.

\section{Conclusions}

The purpose of this study was to investigate the effect of perceiver's gender, clothing, and hairstyle on the visual evaluation of men's professionalism and preference. The subjects were 208 men and 223 women in Seoul, Korea.

Men's hairstyle gave significant influence on evaluation of professionalism. The short hairstyle was evaluated to be more professional than the medium length. Clothing gave significant influence on evaluation of potent image and intellectual image. A beige sweater was evaluated high in intellectual image, a red jumper was perceived low in intellectual image, and a beige tailored collar jacket was evaluated low in potent image.

There were significant interaction effects in evaluation of professionalism according to two variables, clothing and perceiver's gender or hairstyle. Women evaluated the beige colored jumper to be less professional than men did. The red sweater was perceived to be more professional by women than by men. The medium length hairstyle was considered to be more professional than the short hair in the men wearing the beige jacket, while the short hairstyle was considered to be more professional than the medium length hair in the men wearing the red sweater.

Men evaluated short hair more intellectual and medium length hair was less intellectual than women did. However, the short hair was perceived to be less intellectual than the medium length hair when men wore the red jumper.

There were significant differences in preference evaluation according to clothing and hairstyle. Short hair was preferred to medium length hair. Beige colored sweater was preferred the most, and beige jacket was preferred the least.

There were significant interaction effects in evaluating preference by perceiver's gender with clothing, and by perceiver's gender with hairstyle. In the case of women, the preference of tailored collared jacket and soutien collared jumper was similar, but the jumper was preferred to the jacket in the case of men. Men liked the beige jumper and the dark blue jumper much more than women did. Men's preference of the beige jacket was the lowest. In the result of interaction effects in evaluating of preference by perceiver's gender and hairstyle, men liked the short hair more than the medium length hair, but women showed evaluated the both hair styles similarly. The men wearing the soutien collared jumper with the short hair were evaluated positively and the tailored collared jacket with the medium length hair were evaluated negatively when the attires were coordinated with the jean pants.

The results of multiple regression analysis revealed that to both men and women, potent and intellectual image of men's appearance was important when they evaluated preference. However, compared to men, 
women considered mature and confident image more important when evaluating preference.

It is concluded that high scores were given to the medium length hair with the beige jacket, and the short hair with the red sweater in terms of the professional image; the results can be interpreted that clothing and hairstyle interacts with each other to make effects on the professionalism evaluation. Also, male perceivers showed more positive feedback towards the jean pants with the casual jumper than the jeans with the tailored collared jacket, which indicated that men showed more conservative and rigid attitude towards the outfit than women.

This study has limitations that the image variation caused by the coordination of upper and lower clothes was not taken into account. The model for the stimuli was wearing a same pair of jean pants with only upper wear changed in styles and colors. It will be necessary to compare various casual wears and formal wears by investigating differences in visual evaluation according to the combination of upper and lower clothes in the future studies.

\section{References}

Behling, D. (1995). Influence of dress on perception of intelligence and scholastic achievement in urban schools with minority populations. Clothing \& Textiles Research Journal, 13(1), 11-16.

Ha, K., \& Lee, M. (2008). A study of the image in men's hairstyle depending on hair color and texture. The Research Journal of the Costume Culture, 16(2), 293304.

Han, M., \& Ha, H. (2003). A study of the sex-role perceptions reflected upon the term "be like ". The Research Journal of the Costume Culture, 11(5), 767-777.

Jeong, Y. (1982). Social psychology. Seoul: Panmunsa.

Joo, S., \& Lee, K. (1999). A study on the visual evaluation for the combination of 'clothing and ground'. Journal of the Korean Society of Clothing and Textiles, 23(1),
$78-89$.

Kim, J. (2002). Introduction in psychology. Seoul: Hakjisa.

Kim, J., \& Kim, H. (1992). The effect of garment category, fashionability and wears' body type on impression formation. Journal of the Korean Society of Clothing and Textiles, 16(4), 371-378.

Kim, J., \& Ryu, J. (2004). Interaction effects of two salient cues on males fashion images: Hair lengths and hair colors. Journal of the Korean Society of Clothing and Textiles, 28(9/10), 1320-1328.

Lee, H., \& Kim, J. (1998). The effects of garment formality, colors, contexts on male high school teacher's impression: Male and female high school students' in Taejeon area. Journal of the Korean Society of Clothing and Textiles, 22(3), 312-320.

Lee, H., \& Yang, H. (2007). A study on the effect of preferable of male college students hairstyles in men's hairstyle trend. The Korean Society of Cosmetology, 13(2), 609-619.

Lee, J. (1993). A study on the casual collar for men and the impression formation. Unpublished master's thesis, HongIk University, Seoul.

Lee, S., \& Koh, A. (1995a). The effect of clothing type and facial attractiveness of men clothed on impressions (I). Journal of the Korean Society of Clothing and Textiles, 19(2), 230-241.

Lee, S., \& Koh, A. (1995b). The effect of clothing type and facial attractiveness of men clothed on impressions (II). Journal of the Korean Society of Clothing and Textiles, 19(4), 565-579.

Pancer, S. M., \& Meindl, J. R. (1978). Length of hair and beardedness as determinants of personality Impressions. Perceptual and Motor Skills, 46. 1328-1330.

Peterson, D., \& Curran, J. P. (1976). Trait attribution as a function of hair length and correlates of subjects preference for hair style. Journal of Psychology, 93(2), 331339.

Rees, D. W., Williams, L., \& Giles, H. (1974). Dress style and symbolic meaning. International Journal of Symbology, 5, 1-7.

Thurston, J. L., Lennon, S. J., \& Clayton, R. V. (1990). Influence of age, body type, fashion, and garment type on women's professional image. Home Economics Research Journal, 19(2), 139-150. 


\section{요 약}

본 연구는 지각자의 성별, 의복, 헤어스타일이 남성의 전문성 및 선호도의 시각적 평가에 미치는 영향을 조사하는데 그 목적이 있었다. 연구방법은 준실험방법이었으며, 실험설계는 $2 \times 8 \times 2$ (지각자의 성별 $\times$ 의복 $\times$ 헤어스타일)의 요인설계를 사용하였다. 자극물은 20 대 남성의 사진 16 장이었다. 의복은 베이지색과 남색의 테일러드 칼라 재킷, 베이지색, 남색, 빨강색의 점퍼와 스웨터였고, 하의는 청바지를 착용하였다. 헤어스타 일은 길이에 따라 짧은형과 중간형으로 구분하였다. 조사대상자는 서울지역의 남성 208명과 여성 223명이 었다. 청바지와 함께 베이지색 스웨터를 착용하는 것은 지성적 이미지가 높게 보였고, 빨강색 점퍼의 착용 은 지성적 이미지가 낮게 보였으며, 베이지색 재킷은 역능적 이미지가 낮게 평가되었다. 남성의 짧은 헤어 스타일은 중간형 헤어스타일보다 전문성이 높게 평가되었다. 남자 지각자는 여자보다 짧은 헤어스타일을 더 선호하였으나 여자는 헤어스타일 선호도가 유사하였다. 여자는 테일러드 칼라의 재킷과 수티앵 칼라의 점퍼에 대한 선호도가 유사하였으나 남자는 재킷보다 점퍼의 선호도가 더 높았다. 베이지색 재킷에는 중간 형 헤어스타일, 빨강 스웨터에는 짧은 헤어스타일이 전문성이 높게 평가되었다. 남자 지각자는 청바지에 수티앵 칼라의 점퍼를 착용한 것을 청바지에 테일러드 칼라의 재킷을 착용한 것보다 더 긍정적으로 평가 함으로써 남자가 여자보다 옷차림에 대해 보수적인 태도를 나타냈다. 또한 청바지 차림에서는 점퍼를 입고 짧은 헤어스타일을 한 남자가 긍정적으로 평가되었고, 재킷을 입고 중간형 헤어스타일을 한 남자는 부정적 으로 지각되었다. 결론적으로 베이지색 재킷에는 중간형 머리, 빨강 스웨터에는 짧은형 머리가 전문성이 높게 보였으므로 의복과 헤어스타일이 상호작용하여 전문성 평가에 영향을 준다고 할 수 있다. 